\title{
Responsabilidad social y Bolonia
}

\author{
Albert Oriol Bosch
}

El mandato de Bolonia está impregnado de un mensaje claro: las universidades son instituciones con una clara función social que deben desarrollar con plena responsabilidad. Esta responsabilidad social (accountability) implica no tan sólo hacer lo que se debe hacer para atender las necesidades presentes y futuras de la sociedad a la que sirve, sino también rendirle cuentas de lo que hace, por qué hace lo que hace y no otras cosas, y que lo hace además como debe hacerse de acuerdo a los tiempos.

Respecto a lo que se hace, Bolonia pide que las titulaciones profesionales se caractericen por la 'empleabilidad' de los egresados, es decir, que ofrezcan titulaciones para las cuales exista una demanda social. Esto no quiere decir, naturalmente, convertir la universidad en una 'escuela de artes y oficios'. La universidad deberá cultivar además el humanismo, la ciencia y la cultura en sus justos términos. Ahora bien, deben acabarse los tiempos en los que la universidad se guiaba exclusivamente por sus necesidades vegetativas. Los tiempos en que una universidad concreta ofrecía más de 450 cursos para unos 500 y pocos alumnos porque disponía de los profesores para ello, deben acabarse. La cuestión prioritaria no es el crecimiento o el mantenimiento de una plantilla de profesores que después ajustarán a sus disponibilidades la oferta docente. La cuestión debe ser el ajuste de los recursos educativos, humanos o instrumentales, a los proyectos formativos de interés social. Interés social que debe contemplarse tanto desde la perspectiva de inmediatez como de futuro, es decir, intentar dar respuestas tanto a los retos del presente como a los previsibles del futuro.

Esta no es sólo una cuestión local. Es una cuestión global que concierne a todo el mundo, tanto en la vertiente cualitativa (qué clase de egresados produce la universidad y de qué calidad competencial) como también cuantitativa (cómo redistribuye la

\section{Social accountability \\ and Bologna}

\author{
.
}


universidad sus recursos para producir un número determinado de titulados de cada titulación). La comisión independiente de The Lancet recientemente analizaba la formación de las profesiones sanitarias (médicos, enfermeras y salubristas) como un conjunto y los retos a los que es preciso enfrentarse globalmente [1], trabajo que comenta A. Segura en este número. También en este número publicamos el recién consensuado documento sobre 'responsabilidad social de las facultades de medicina' [2], que desde una perspectiva global representa la aplicación concreta de este reto de Bolonia a las facultades de medicina.

Mutatis mutandis, parecida reflexión a la de la función educadora de la universidad puede hacerse con la función investigadora o creadora de nuevo conocimiento. Con recursos limitados, situación invariante pues nunca ni en ningún lugar los recursos son ilimitados, la investigación que ésta lleva a cabo debe dejar de dirigirse exclusivamente a los intereses de los investigadores. El conocimiento por el conocimiento no puede ser abandonado por la universidad, pero ésta no puede limitarse a ser el invernáculo de aspirantes a genios. Algunos elementos especiales pueden y deben coexistir con individuos dispuestos a poner sus esfuerzos al servicio de la sociedad concreta que le proporciona los medios para crear nuevos conocimientos. Por lo tanto, una cierta parte de la investigación básica ha de ser orientada por prioridades sentidas por la sociedad como importantes, sin menoscabo de su calidad, exigible si dicho esfuerzo quiere ser realmente investigador.

El abundante e incuestionable acerbo de talento que la universidad atesora, a veces encerrado en su torre de marfil, debe orientarse también a la mejora de los servicios que presta, y muy especialmente en el sector de las ciencias de la salud, cuyas funciones docentes e investigadoras se llevan a cabo en una gran proporción en centros académicos que prestan asistencia. Dichos centros asistenciales de carácter académico tienen que contribuir significativamente a la introducción de las mejoras de los servicios prestados a la sociedad para justificar su coste superior al de las otras organizaciones asistenciales no académicas.

Si las universidades, y en nuestro caso las facultades de medicina, no son capaces de exhibir una alta responsabilidad social, rindiendo cuentas de lo que piensan hacer y cómo piensan mejorar su orientación a las prioridades sociales, estarán incumpliendo una de las premisas del proceso de Bolonia. No valdrá la alegación, cierta por supuesto, de la necesidad de recursos, si no puede exhibir un mission of The Lancet recently analyzed the world production of health professionals (physicians, nurses and public health officers) and the global challenges we face worldwide [1]. A. Segura in this issue extensively comments this document. Also in this issue we publish the consensus document that from a global perspective with the Social Accountability of the Medical Schools [2] deals with the Bologna's challenge as it concerns de Medical Schools.

Mutatis mutandis, similar considerations concerning the Universities' knowledge transfer or educational function could be carried out in relation with their knowledge generation or research function. With limited resources, a steady situation since never and nowhere resources have been unlimited, the research that is being done at the Universities should not be exclusively concerned with the personal interests of the researcher. While knowledge as an end by itself can not be fully disregarded by the Universities, they should not become the greenhouse for a bunch of genius candidates. Some such specimens can coexist with others prepared to put their capacities and efforts at the service of the society that provides the means to create new knowledge. Therefore, some of the basic research ought to be directed towards important scially perceived needs, going without say, that quality is, in any case, a constant requirement also in all kind of research that deserves to be called so.

The abundant amount of talent the Universities possess, often isolated into the ivory tower, should also become interested in the improvement of the services provided by the Universities, specially so in the field of the health sciences, which educational and research functions are mainly carried out in the academic health care centers. The academic health care centers should contribute significantly to the improvement of the care delivered to the population in order to justify their higher costs.

If the Universities and their Medical Schools do not show a high degree of social responsibility accounting for their attempts to deal with the social priorities, they will not be complying with the Bologna's mandates. Arguing that they can't because of a shortage of money, an ever present reason, will not be satisfactory argument to justify them if they can not show their previous efforts to align with the societal needs the use of the remarkable amount of resources and talent they accumulated.

The necessary change in the Universities, in general, and the medial Schools, in particular, comes not only from the expansion of the scientific knowledge but also as consequence of an increment of democratic culture of the population, that now expects that their publicly financed institutions, inde- 
esfuerzo por acertar en la alineación social de sus actividades y un mejor uso de los recursos que tiene, cuya acumulación a lo largo del tiempo no es nada desdeñable.

El cambio necesario en la universidad, en general, y en las facultades de ciencias de la salud y muy especialmente en las de medicina, en concreto, no es sólo el que se deriva del progreso científico-técnico, sino que también es consecuencia del incremento en cultura democrática de la sociedad, la cual aspira a que sus instituciones, por seculares y prestigiosas que sean, tengan en cuenta sus prioridades. Mal harían en obviar lo que se comienza a airear alto y claro. pendently of how ancient and prestigious they are, should take into account the social needs and priorities. Not attending to what begins to be said loud and clear would be dangerously wrongdoing.

Bibliografía / References

1. Frenk J, Chen L, Bhutta ZA, Cohen J, Crisp N, Evans T, et al. Health professionals for a new century: transforming education to strengthen health systems in an interdependent world. Lancet 2010; 376: 1923-58.

2. Boelen C, Wollard RF (copresidentes). Consenso Global sobre la Responsabilidad Social de las Facultades de Medicina. Educ Med 2011; 14: 7-14. (Versión inglesa: http:// healthsocialaccountability.sites.olt.ubc.ca/files/2011/01/ GCSA-Consensus-Document-English.pdf).

En el editorial correspondiente al número 13 (3), se omitió hacer referencia al trabajo: 'Guía para la evaluación de las competencias en Medicina', coordinado por el Profesor J. Carreras Barnés, publicado por la Agència per a la Qualitat del Sistema Universitari de Catalunya, y de gran relevancia en relación al contenido del referido editorial. La publicación se puede consultar en: http://www.aqu.cat/publicacions/guies_ competencies/guia_medicina_es.html. 
